\title{
回想分析を用いた旧街道商店街の街路イメージの分析*
}

\section{A Study on Image of Old High Streets Using Analysis of Memories on The Street*}

\author{
亀谷一洋**・山中英生 $* * *$ 三宅正弘 $* * *$
}

By Kazuhiro KAMETANI** • Hideo YAMANAKA*** • Masahiro MIYAKE***

\section{1. はじめに}

わが国には, 街道筋沿いに商店街として発達した 中心街が多く見られる。しかし，近年の交通需要の 増大に対応するため, 中心街を迂回するバイパスが 多くの町で整備された結果, 旧街道筋が裏道化し, 町の中心商店街が衰退するという現象が相次いだ. バイパス整備の目的は通過交通の排除によって市街 地の交通状況の改善を図ることにあるが，実際には 町としての活力をそぐというジレンマに陥っている. 英国ではバイパス整備にあわせて旧道の歩行者化や 活性化をパッケージ1) する整備例が見られるが，わ が国では体系的に取り組んだ事例は少ない。このた め, 旧街道筋住民には, 旧道の利用方法や, 現状に ついての不満も高い.

本研究は，このような旧街道商店街の再生方法を 考える第一のステップとして，バイパス裏道化とい う歴史的推移を経験している沿線住民の市民意識を もとに, 街路再生のコンセプトの抽出を行うことを 目的としている.

そのため歴史的な変遷を経験した旧街道商店街に おいて, 沿線住民にインタビュー形式のヒアリング を行い，沿線住民が持っている街路イメージと旧街 道型商店街が潜在的に持つ街路としての魅力を再利 用して, 旧街道型商店街の街路再生方法を提案する ものである.

街路のイメージに関する研究は, 安藤ら ${ }^{2)}$ が, さ まざまな街路を事例に，そのコンピューター・グラフ イックスを用いてのイメージの定量化をおこなって いる. 平野ら ${ }^{3)}$ は, 繁華街での街路イメージの類型 を明らかにしている。

*キーワード : 地区交通計画, イメージ分析, 市民参加

**学生員, 徳島大学大学院工学研究科

(徳島県徳島市南常三島町 $2 丁$ 目 1 番地)

***正員, 工博, 徳島大学工学部建設工学科

(徳島県德島市南常三島町 2 丁目 1 番地,

TEL088-656-7350， FAX088-656-7579)
本研究では, 德島県の羽ノ浦町商店街を事例とし て,この旧街道商店街に焦点を当て, 回想分析法を 用いて, 沿道住民が持つ旧街道商店の街路イメージ の分析を試みた。

\section{2. 羽ノ浦町商店街の現状}

羽ノ浦町は, 徳島県の南部に位置し, 県都徳島市 から南に約 $15 \mathrm{k} \mathrm{m}$ の距離にある, 面積 $8.9 \mathrm{~km}^{2}$, 人口 約 12,000 人の町である.

羽ノ浦町商店街は, 羽ノ浦町の中心部に位置する 延長約 $800 \mathrm{~m}$, 幅員 $6 \sim 10 \mathrm{~m}$ の旧国道沿いに発展した 旧街道商店街で, 古くは土佐街道として徳島県と高 知県を結ぶ幹線街道上にあった。昭和初期には, 一 部道路の両側に幅 $2 \sim 3 \mathrm{~m}$ の用水が流れていたが, 昭 和 7 年頃から順次, 蓋がかけられ，昭和 27 年頃に商 店街部分は全線蓋がかけられ，現在の道路断面形状 が形成された．さらに，昭和 44 年に商店街を迁回す

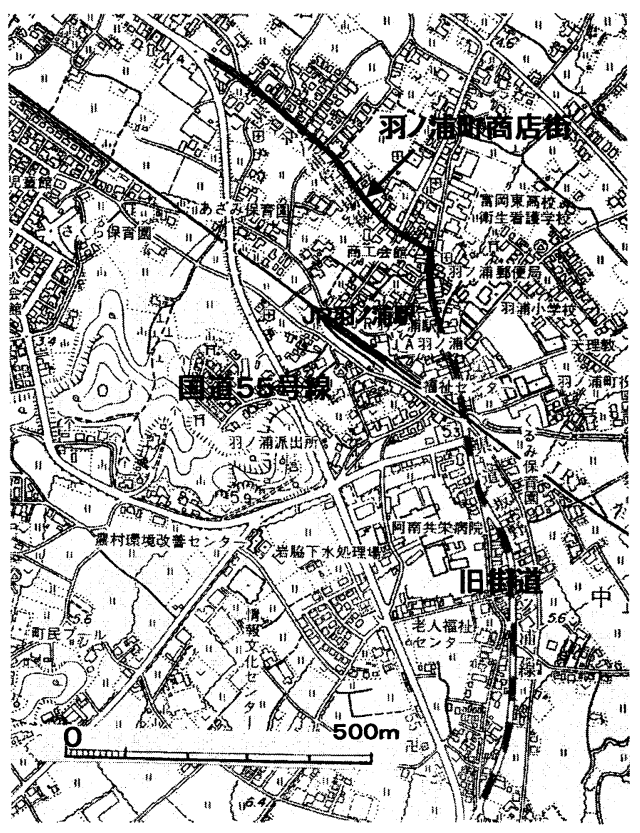

図一 1 羽ノ浦町商店街位置図 
る国道バイパスが完成し，旧街道は県道となる。現 在, 商店数は 43 店舗, 民家は 37 軒, その他 3 軒と なっている。

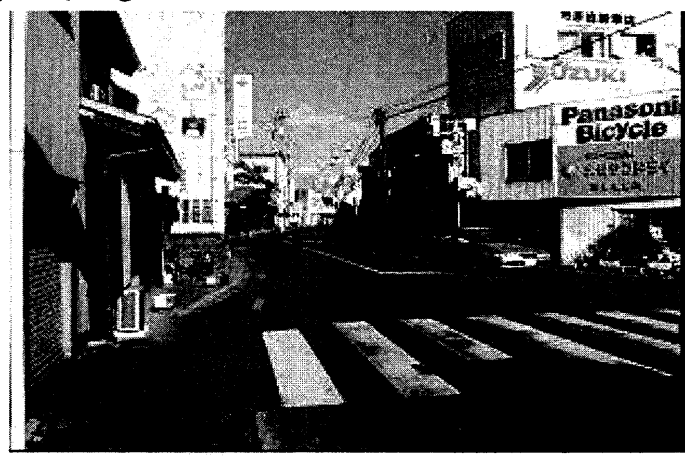

写真一1 羽ノ浦町商店街の現況

\section{3. 回想分析による沿道住民への個別ヒアリング}

本研究では，上記のような変遷を持つ街路に対す る沿道住民の意識を調べるために，回想分析と呼ぶ 方法を試みた。ここで回想分析とは，今までの日々 の生活において, 前の道路で思い出す楽しかった（よ い) イメージ，わるいイメージを被験者 1 人 1 人に インタビューし，その要素と連関を分析する方法で, 臨床心理で用いられる重要事項分析の手法を道のイ メージ抽出に改良したものである.

被験者は，住民 8 名を対象で，50 代から 80 代の 男性 7 名，女性 1 名である．今回は，被験者の年齢 属性に偏りがあるが，過去の道路に関するイメージ を思い出してもらうため, 対象道路に接して生活し ており，地域に住んでいる期間の長い年輩の人の意 見をきくことが重要と判断した. また，インタビュ 一には十分な時間 (30 分〜1 時間以上/人)をかけ, その内容の分析と考察に主眼を置くため，被験者数 は少なくなっている.

インタビューの手順を以下に記す。

1）被験者に「家の前の道で思い出す,よいイメージ, わるいイメージの出来事や体験したことを何でも 自由にお話ください.」と問いかける.そして発言 内容の時代や被験者の気持ちを確認するため,「そ れはいつの頃の話ですか.」とか「そのときあなた はどう思いましたか.」などの質問をはさみながら， その時の道路状況を具体的に話させ,イメージの年 代を確認する.

2) 引き続き，「他に家の前の道で思い出す，よいイ メージ,わるいイメージの出来事や体験したことは ありませんか.」と問いかけ，そのイメージの年代 を確認する.被験者に自由に話をしてもらうことを 目的とし，インタビューアは，聞き手に徹して，時 代や道路状況を確認する問いかけのみを行うよう
に注意し，この問いかけを繰り返し行う.

インタビューは, 平成 13 年 11 月と平成 14 年 6 月に数回に分けて行った。一連のインタビューは全 てテープに録音している. 以後, 被験者に対して,「家 の前の道」という言葉で説明しているため, 文中で ヒアリングに関係するところは, 街路ではなく, 道 路と表現している.

\section{4. 回想分析の結果と考察}

\section{（1）イメージラダーでの分析}

次に発言項目の内容を分解し, D.N.Hinkelによっ て開発されたラダーリング技法 4) を参考に以下の方 法でイメージラダーを作成した.

たとえば，「夏祭りに人がたくさん来てくれて楽し かった.」という発言は, 発言を「夏祭り」, 「人がた くさん来てくれた」,「楽しかった」に分ける.

そして全体の概念である「夏祭り」を上位項目に, 具体内容としての「人がたくさん来てくれた」を下 位項目として配置し図上では矢印で示す。そして,

「楽しかった」はよいイメージに分類する. 図では, わるいイメージのみム印で表している.

結果を図-2 に示す.これから，以下のことがわか る.

(1) 道路に対して持っているイメージは, 交通に関す る発言が多かった。しかし, その内容は自動車交通 の発達とともに, 自動車やバスを時代の象徴として 誇らしくみる時代から，それらが一般的に普及する ことにより, 長所短所併せ持つ日常的乗り物として みている発言に変わってきている. また, 8 名全員 が用水についての発言をしていて, 昔あった用水を 沿線住民はよく覚えているといえる.夏祭りなどの イベントと商店街の状況についての発言は 5 名と なっている. 景観についての発言は 2 名であった.

(2) 時代の変遷により, 被験者の家の前の道路につい て持っているイメージが交通に関する項目に移っ ていることがわかる.これに対して, イベントや商 店街の状況は, 昭和初期から戦後まもなくまでは項 目として多くあげられてきたが，昭和 44 年のバイ パス開通後からは, 過去を懐かしむイメージとして の発言しかなく, 商店街としての活力の低下が感じ られる。

(3) 以前に道路に沿って流れていた用水については, 危険というイメージと, 自然を感じ, 楽しんだとい う, 両方のイメージを持っている. 用水路に蓋がか かって, 用水に落ちる危険はなくなったが, 自動車 や自転車が家の際までくるようになり, 危険になっ たと感じる人もいた.

(4) 被験者は, 夏祭りなどのイベントや商店街での 


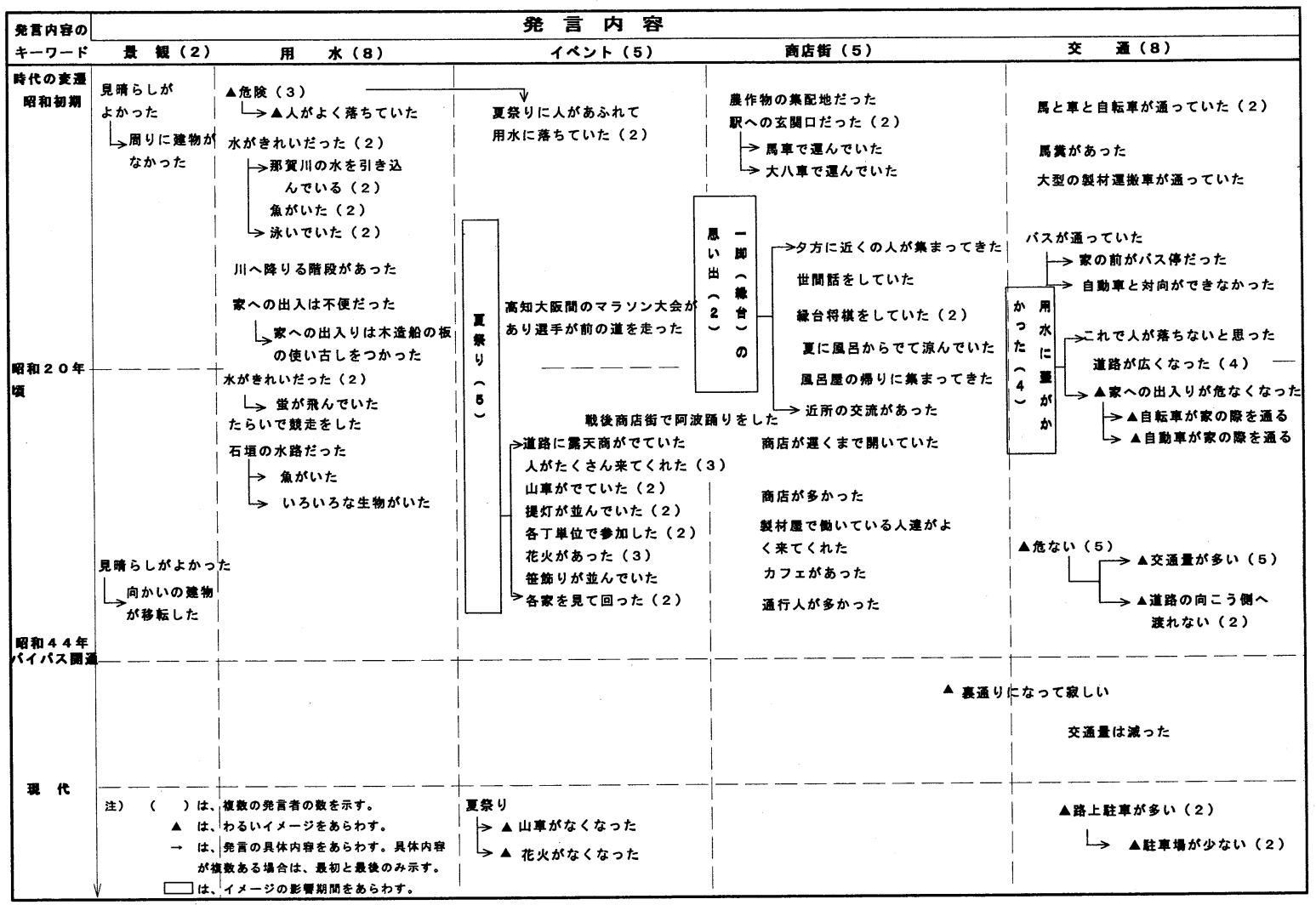

図一2 個別ヒアリングでの発言内容

商業活動や日々の生活といったソフトな部分には わるいイメージはないが（現在の状況を過去の賑 やかだったころに比べて寂しいと思う意見はあ る.), 用水や交通に関しては, よいイメージとわ るいイメージの両方を持っていて, 被験者の評価 が分かれている. これは, 今日の道路の新設, 改 良に対する地権者の意見の多様性に相通じるとこ ろがある。

上記(1)〜(4)をもとに，次のキーワードを抽出した.

a. 交通

被験者 8 名全員が, 道路上での交通の話をし, その話の内容は話の年代によって変わってきて いるが，交通に関する関心は高い.

b. 用水

被験者 8 名全員が, 昔, 道路に沿って流れてい た用水の話をしている.内容については用水で何 かをしたという思い出がよい思い出として，記憶 に残っている.

c. イベント

被験者のうち 5 人が夏祭りの様子を楽しそう に話してくれた. 夏祭りに人がたくさんきて賑や かになるのをよい思い出としてもっていること がわかった. 現在の夏祭りについては街中の祭り
ということもあり花火ができなくなり, 山車もな いなどの状況を寂しく思っている.

d. 商店街

被験者は昔の繁栄の様子を話してくれた. 日常 的な情景としての夕方の縁台将棋は, 被験者の思 い出に残っているようだ.

e. 景観

景観については, 当初予想していたほどの発言 者はいなかった. 日常生活の中で, 隣の建物が建 て変わったり, 撤去されたりしたことの思い出は, すぐには思い出しにくいと感じた.

\section{（2）最初の発言内容}

次に 8 名の被験者がインタビューの中で最初に話 した項目を聞き取り表-1に表した. 被験者数が 7 名 になっているが, 残り 1 名は, 全く道に関係ない話 題から始まったため除いている.

表-1 より, 水路に関することが(1), (3)を併せて 4

表一1 被験者が最初に話した内容

\begin{tabular}{|c|l|c|}
\hline & \multicolumn{1}{|c|}{ 最初に話した内容 } & 人数 \\
\hline (1) & 夏祭りに人があふれて、水路に落ちていた & 2 \\
\hline (2) & 一脚(縁台)でのコミュニケーション & 2 \\
\hline (3) & 以前にあった水路の一般的な話 & 2 \\
\hline (4) & 道路の現況に対する不満や願望 & 1 \\
\hline
\end{tabular}


名，一脚（縁台）とそこでのコミュニケーションが 2 名, 夏祭りが(1) 2 名, 道路の現況の話が 1 名と なっている. 被験者の一番印象に残っているイメー ジが, 最初の発言にでてくると仮定すると, 被験者 の多くは, 昔, 道路に沿って流れていた水路のイメ ージが強く残っているといえる.

\section{（3）道路情景再現図への展開}

続いて, 図-2 のヒアリング内容を日常的生活, 非 日常的生活発言に分け, 日常的な発言を道路平面上 に道路情景再現図として展開し, 非日常的生活上の 発言を表形式で表した. 各発言内容を水路に蓋が掛 かる前, 蓋が掛かってから国道バイパス開通まで, 国道バイパス開通後の 3 つの時期に分けている. 図 -3 より水路に蓋が掛かる以前の昭和 20 年前後までは, 普段の生活で, 沿線住民は道路と水路の両方を利用 しているが，水路についてはくつろぎの場や井戸端 会議などコミュニティーの場として家の際の持つ半 私的空間に近い利用方法がなされており, 車道部分 との利用形態の棲み分けがなされているといえる.

蓋が掛かってからバイパス開通までは, 外部空間に 道路と家の際との緩衝帯であった水路の役割をはた すものがなくなり, かつ, 旧街道商店街の建物配置 は写真-1 からもわかるように前面道路に面して建築 されているため, 敷地前面に人のたまり場空間がな いので, 井戸端会議などコミュニティーの場は, 交 通量の増加もあり, 外部空間上から消滅してしまっ ている. 同時代に起ったモータリゼーションの発達 による自動車交通の増加は, 道路反対側への横断の バリアともなり，沿線住民の「交通量の減少，その ためのバイパス建設要望」欲求の一因を生み出して いる. しかし商店街としては, 他の地域の製材所で 働いている人たちが買い物にきてくれるなど活気が あった時期である. バイパス開通後は, 近くに駐車 場を持った大型店ができた時期とも重なり, 交通量
は減り，路上駐車が残る裏通りとなっていることが 道路情景再現図からもわかる。

\section{(4) 考察}

図-2より，被験者の発言が多い時代は，旧道がま だ本通りであったときで，商店街も繁栄していて， 道路上で祭りなどのイベントに参加したり，遊びを 体験できた時代であった，そのような状況の道路を 心地よく感じている傾向がラダー図から考察される.

\section{5. フォーカスグループミーティングによる回想 分析}

\section{（1）グループの属性}

次に，世代の違う人達の意見を聞くために，2つ の違った年齢層の人達に別々に集まってもらい, 同 じように今までの日々の生活において, 対象道路で 思い出す楽しかった（よい）イメージ，わるいイメ ージを自由に話し合ってもらい，その要素と連関を 分析した. 質問方法は個別ヒアリングと同様である.

参加者は, 両グループとも, 研究対象道路の沿道 に住んでいる人, および研究対象道路から徒歩圈に 住んでいる人々である.それぞれの年齢層および性 別を表-2 に示す. フォーカスグループミーティング は, 平成 14 年 5 月から 6 月にかけて行った.

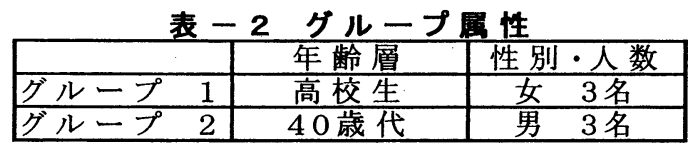

\section{（2）女子高校生グループの回想分析}

図-4 はグループ 1 の女子高校生の持つ旧街道商店 街のイメージラダーである.これより以下のことが わかる.

(1) 保育園の頃, 対象道路に接して住んでいた人は, 道路に飛び出して車とぶつかりかけた経験があり，

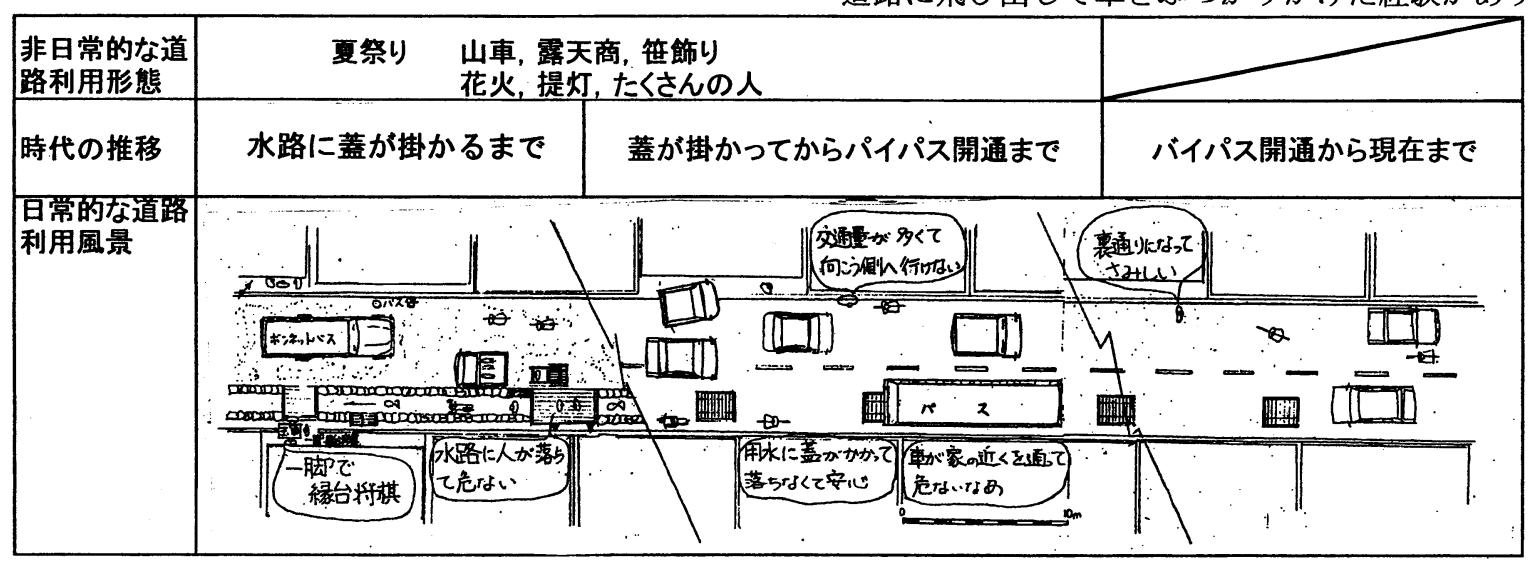

図一3道路情景再現図 
そのイメージを鮮明に覚えている。

（2）小学生の頃は，活動範囲が広がり，商店街のさま ざまな店屋へ行った思い出があり, 移動のための交 通手段として, 自転車を使い始めている.このため, 自転車を利用する上で障害となる路上駐車に対し てわるいイメージを持っている. また，この頃の夏 祭りのイメージをとても楽しかったイメージとし て覚えている。

(3) 中学生では, 夏祭りに対する項目は小学校ほどで はなくなったが, 兄ががんばって造った山車のこと を楽しそうに話してくれた. 自転車で走行時の路上 駐車車両の危険性は, 中学生の時も変わっていない。

(4) 現在（高校生）は, 祭りについては, 懷かしい友 達に会えるなどよいイメージを持ち続けているが, 商店については，店に入りづらかったり，店が開い ているのかわかりにくいため, あまり利用しなくな っている.

(5) 将来の希望としては, 商店の内容に対する希望と, 道路の形態に対する希望, 商店 (建物) と道路の距 離関係についての希望があがった。

上記(1)〜(5)をもとに，次のキーワードを抽出した.

a. イベント

夏祭りの様子については, 準備の様子や祭りの日 の様子を鮮明に覚えていて, 道路上でのイベントと
してのインパクトは強いことがわかる.

b. 商店

被験者は，発言の中で，具体的に個々の店の利 用方法や，その道筋での出来事の発言が目立った. c. 道路

現在高校生である被験者たちは，商店と彼女た ちのもつとも利用頻度が高い交通機関である自転 車を結ぶ媒体として道路がある．また，年少の頃に 家の前の道路で交通事故に遭いかけた出来事は道 路上での思い出として深く脳裏に残っているなど, 道路は路上駐車も含めてどちらかといえばよくな いイメージの場として捉えている.

d. 自転車

被験者たちは小学生の頃から自転車を頻繁に使 つているため, 自転車が快適に走れる環境の道路を 希望している.

次に, 表-3 に女子高校生グループが話した話題の 順序を示す.

今回はフォーカスグループミーティングのため,

表一３ 女子高校生グループの発言順序

\begin{tabular}{|c|l|}
\hline 発言順序 & \multicolumn{1}{|c|}{ 発言内容 } \\
\hline 1 & 路上駐車が邪魔で自転車が通れない \\
\hline 2 & おもちややへ通った思い出 \\
\hline 3 & 夏祭りの情景 \\
\hline
\end{tabular}

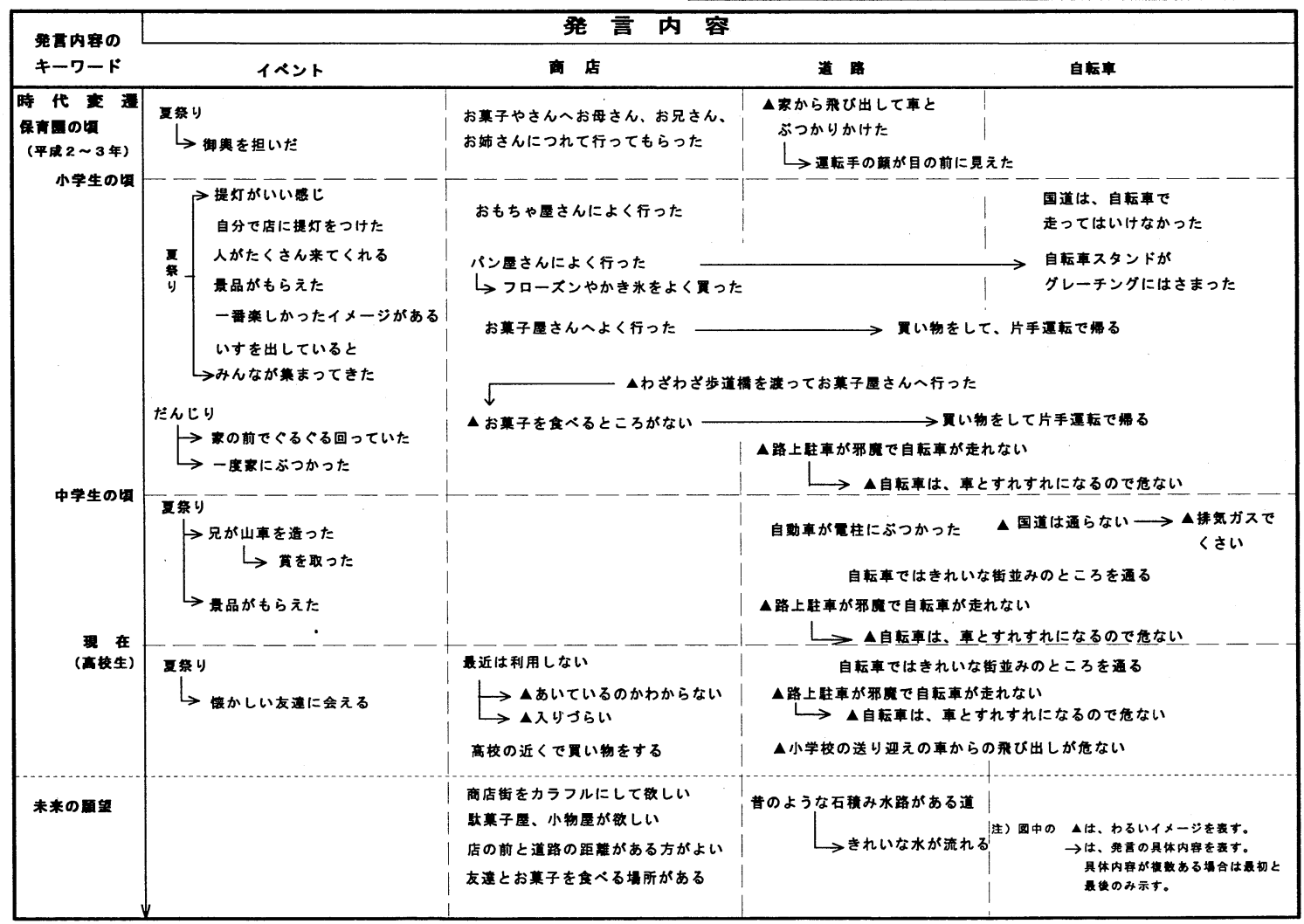

図ー4 女子高校生グループの発言内容 
発言順序は, 最初に話を始めた人の内容に他のメン バーが影響を受けることは仕方がないが，発言順序 で上位に上がってくる発言内容は，発言者が道路に 対して感じている強い思いに違いないと判断した. 表-3 及び図-4 の中で路上駐車の発言順序が 1 位で, 各年代の道路イメージにもでてくることより，今回 参加した女子高校生たちは, 自分たちが普段利用す る交通手段である自転車通行時の道路上での路上駐 車の状況を道路のイメージとして強く描いていると いえる.

\section{（3） 40 歳代男性グループの回想分析}

図-5 にグループ 2 の 40 歳代男性の持つ旧街道商 店街の道路イメージを表す。これより以下のことが わかる.

(1) 全体として道路・交通についての発言が多い. 祭

りについては小学校時代の祭りのイメージが大き く,グループ 1 の高校生のように小さい頃の祭りの イメージを現在まで楽しいイメージとして持って いるということはない.

(2) 旧街道商店街筋に住んでいる人は, 小学校 1 年の 時に家から出たところで自動車につま先を踏まれ た時の状況や自動車のドアを開けたときに後続車 にドアがぶつかった時の状況を鮮明に覚えている.
(3) 小学生の頃は, 道路の下にある用水に入って遊ん でいた経験を持っている. 道路の下にある用水路網 を知っている最後の年代だと自負していた.

上記(1)〜(3)をもとに，次のキーワードを抽出した.

a. 用水

用水については, 4 章の年齢層が高い被験者ほど 発言はなかったが, 用水路に蓋がかかっても, 地下 の水路網を熟知していることを自慢していて, 用水 は被験者のイメージに残っているといえる.

b. イベント

被験者たちが頻繁に参加したころの夏祭りのイ メージは鮮明に覚えており, 店の種類や, 小学校を 解放しての書道展などをよいイメージとして持っ ている.

c. 商店

国道バイパスができた時期が小学校の高学年か ら中学生の時期で当時の様子を覚えていた. バイパ ス沿いにショッピングセンターができたことや交 通量が減り, 夜に道路で遊んだことなど, 当時はバ イパス開通に伴う環境の変化をよいイメージとし て感じていた.

d. 道路・交通

高校生の被験者と同じで, 道路に面して生活して いる被験者の一人は，交通事故に遭いかけていて，

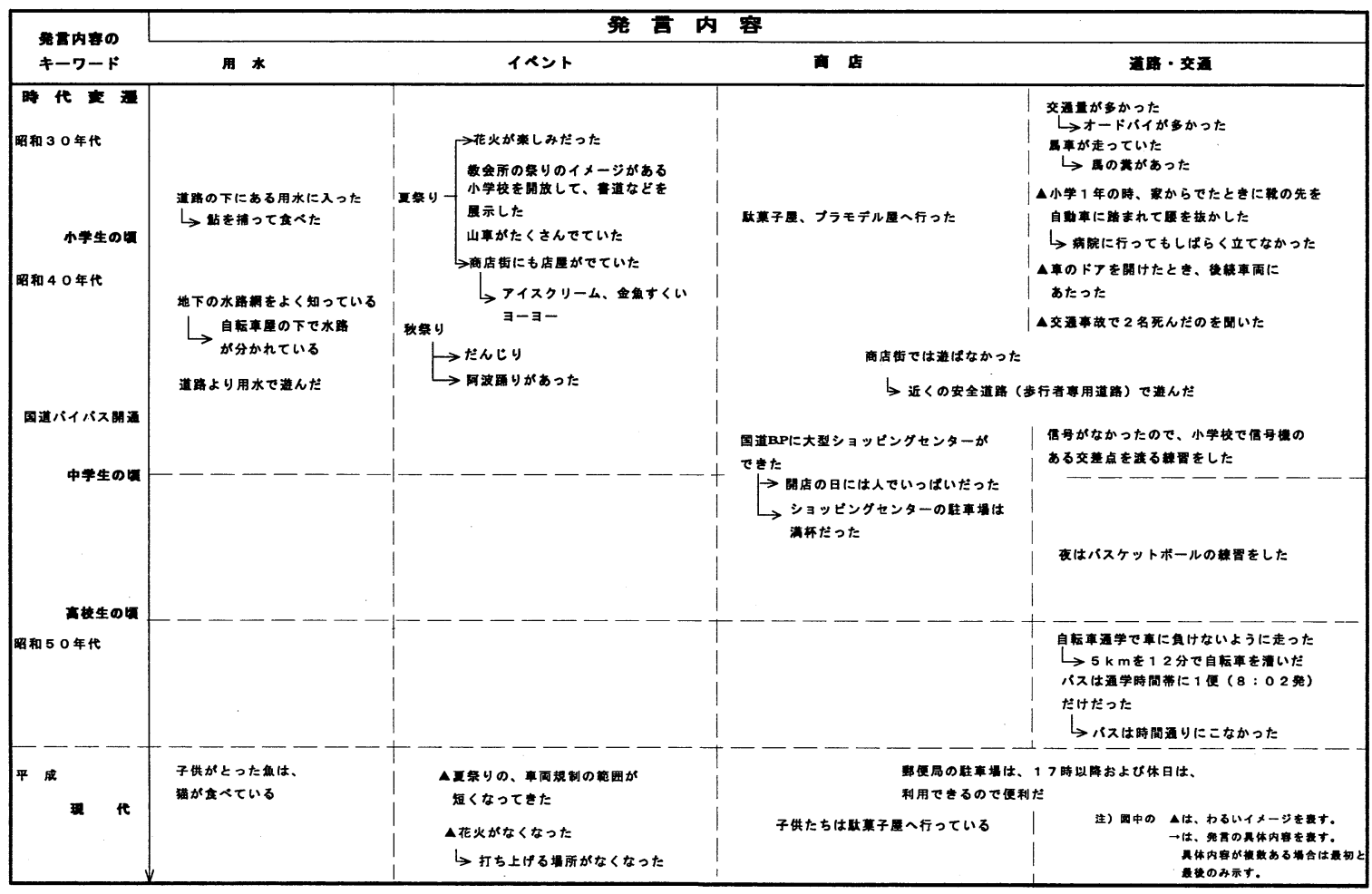

図ー5４0歳代男性グループの発言内容 
そのときの様子を鮮明に覚えている. 交通事故で 2 名が亡くなったということを覚えていて,小さい頃 から，事故が多い道であるという認識を持っている. 表-4 に被験者の発言順序を示す.

\section{表－4 40歳代男性グループの発言順序}

\begin{tabular}{|c|l|}
\hline 発言順序 & \multicolumn{1}{|c|}{ 発言内容 } \\
\hline 1 & 交通量が多かった \\
\hline 2 & 馬車が通っていた \\
\hline 3 & 道路下の用水に入って魚を捕った \\
\hline
\end{tabular}

これより，被験者のこの道路に対して持っている イメージは, 小学生当時の交通状況に関するイメー ジが大きい。これは，図-5 のラダー構造図において 小学校時代の道路交通のイメージ発言が一番多かっ たこと，および国道バイパスが完成する時期であっ た時代背景と一致する。

\section{（4）道路情景再現図への展開}

次にこの 2 グループの発言内容を図-3 と同じよう に年代毎の道路情景再現図に展開することを試みた が，以下の理由で展開が困難であることがわかった。

(1) 高校生グループについては, 道路上での行動がダ イナミックであるため, 1 路線の短い区間では表現 できなかった．すでに車社会の中で生活しており， 道路の形状や交通量の大きな変化を経験していな いため, 年代ごとの発言内容に変化がみられなかっ た.

(2) 40 歳代男性グループについては，小学生の頃の イメージは，図-2 の蓋が掛かってからバイパス開 通までのイメージに近く,これについては, 再現図 への展開が可能であるが, バイパス完成から現在の 道路イメージについての発言が希薄なため, 道路平 面上に展開ができず, 年代ごとの道路情景再現図と ならない.

このことより，今回のような年代ごとの道路情景 再現図作成条件としては, ある期間を持つ年代毎に 道路上の日常生活イメージ発言があり, 道路形態や 利用方法について目に見えて変わった時期を経験す る必要がある。

\section{(5) 考察}

女子高校生の発言と 40 歳代男性の発言を比べると 両グループとも自分たちが道路上で体験した出来事, 例えば夏祭りや用水で遊んだり，交通事故に遭いか けたイメージは，よくもわるくも鮮明に記憶してい るため，発言内容をラダー構造図上に描いたときに 密度が濃くなっている. 特に 40 歳代男性グループに おいては，小学生の頃に道路上で体験したイメージ は強く残っているが，車が日常的に使われる時代に なり，用水路は蓋がかけられたり，コンクリートで
固められたり，祭りも縮小傾向にあるなど，被験者 自身の道路上での日常, 非日常体験が少なくなって きている．高校時代にはバスに乗るためだけに道路 を利用したような感じすらうかがえるが, 30,40 才と 年齢を重㱛るにつれて, 子供達から情報を仕入れた り, 商店街全体のことを考えるようになるなど, 道 路に再び意識を持つようになっているといえる，40 歳代男性グループは, 年配の被験者よりもバイパス 完成から現在の道路状況についての発言があり，道 路状況について普段より観察している傾向がある.

女子高校生については，商店街を自転車を利用し ながら活動的に動き回っている.このため, 普段の 生活で自転車が快適に利用できる道路整備が必要と なってくる，そのためには，路上駐車の問題と，通 過交通量を減らすなどの対策が必要である. 夏祭り については，たくさんの人が来る道路上での楽しい イベントとして捉えていて，これを維持していくこ とが必要になってくる.

\section{6. まとめ}

回想分析法を用いて沿線住民にヒアリングを行い， その結果をラダー構造で表現することにより，沿線 住民の持つ旧街道商店街の街路に対する意識を図上 に表すことができた．発言内容を時間軸上に整理す ることによって, 時代時代における人々の活動の様 子や，普段の生活の中で個人個人が街路に対して持 っているイメージの移り変わりを表現することがで きた．今回用いたヒアリング手法は，アンケート調 査と違い，多くの人々の意見を聞くことはできない が，回想分析を行うことで沿線住民の意識やその連 関を抽出する有効な手段になると思われる.

イメージラダーから見る考察は以下のとおりであ る.

(1) 旧街道商店街沿線住民は, 道路上で何かをしたこ とや, 伝統行事など何か行事に参加したということ に関しては鮮明に覚えている. 人々が道路に出なく なった, 出られなくなったことが道路に対する認識 を旧街道商店街が本来持っていた道路の多面性か ら交通問題のみの一面性へと向かわせている.

(2) 歩行者や自転車利用者にとって, 交通量の減少は 道路利用の快適性を高めるものであるが, 実際には, 路上駐車や路上駐車車両と通過車両の間にはさま れた空間を利用しているため, ストレスの要因とな っている。

(3) 国道から旧道になり，交通面では自動車交通量が 減ってよかった反面, 新しいバイバスに大型スーパ 一等の進出があり,商店街としての機能は低下して いるが, 今も旧道ならではの駄菓子屋に対する人気 
は根強いなど歷史性を生かした店づくりが必要で ある. 現在の商店は, 道路前面に沿って立っている が，建替え時には，建物前面に顋いの空間を設ける のも旧街道商店街の再生の一つの方法といえる.

(4) 夏祭り等のイベントは, 年代を問わず楽しい思い 出となっていて, 道路上に人がたくさんいる状況を 楽しいと感じている.

以上より旧街道商店街の街路再生のコンセプトは 以下のとおりである.

(1) 街路の多様性, 多面性の復活. かつて, 旧街道商 店街は沿線住民が集まって, 情報交換をする場であ ったり, 商売の場であったり, 子供たちの遊び場で あったり,イベントの場であったりと季節や 1 日の 中でも時間帯によって, 交通用途以外にさまざまな 使われ方をしていた. その機能を少しでも再生させ ることが課題といえる.

(2) 楽しみの場を提供する街路. 旧街道商店街の住民 は古くからの伝統に育てられ，それを守りながら生 活している. 祭りなど伝統行事は, これからも旧街 道商店街の街路利用のひとつとして, 維持, 発展さ せていかなければならない。

こうした街路再生コンセプトを実現するために次 のような方法があるのではないだろうか.

(1) コミュニティーの強化. 旧街道商店街は, 郊外型 の商業地区と違い, 歴史のある昔ながらの地域コミ ユニティーが, 衰弱しながらも残っている.このコ ミュニティーを活用し, 夏祭りや商店街のイベント
などを維持, さらには復興していく必要がある。

(2) 街路空間の時間分割利用. 日本各地では日曜市や 朝市が開かれる道路など， 1 週間や 1 日の中で道路 の使い分けを行っているところもある.また，自動 車を完全に封鎖しなくても, 浮沈式のボラード等を 設置することで自動車交通の優先比率や路上駐車 を時間的に調整することができ，自動車・歩行者・ 自転車が共存した新しいタイプの旧街道商店街の 再生が可能になると考えられる.

今後は,こうしたヒアリングの意見や再生コンセプ 卜をもとに, 归街道商店街の具体的整備手法を導く 方法，そのための官民の協働手法について検討する ことが課題である.

\section{参考文献}

1) Report of the Bypass Demonstration Project: Better Places Through Bypass, pp.8-14, 1995.

2）安藤直見，八木幸二，茶谷正洋 : 都市中心部にお ける街路空間のイメージ分布, 日本建築学会計画 系論文集第 497 号, pp.155-162，1997

3）平野勝也，資延宏紀 : 街路イメージ類型を用いた 繁華街構成分析, 土木計画学研究・論文集, No.17, 533-540, 2000

4）讃井純一郎，乾正雄：レパートリー・グリッド発 展手法による住環境評価構造の抽出, 日本建築学 会計画系論文集第 367 号, pp.15-21， 1986.

\section{回想分析を用いた旧街道商店街の街路イメージの分析*}

亀谷一洋 $* *$ ・山中英生 $* * *$ 三宅正弘 $* * *$

近年の交通需要の増大に対応するため, 地方の小規模市町村で中心街を迁回するバイパスが整備され た結果, 旧街道笳が裏道化し, 町の中心商店街が衰退するという現象が相次いだ. 本論文では, 旧街道 商店街の再生方法を考える第一のステップとして, 歴史的経過を経験している旧街道商店街の沿線住民 が前面街路に対して持っているイメージを把握するため，回想分析を用いて，沿線住民に個別インタビ ューを行い, 結果を時間軸上にラダー構造で表現した. また，少人数のフォーカスグループミーティン グの結果も同様の手法で街路イメージの把握が可能であることがわかった。この手法から旧街道商店街 街路再生コンセプトの提案を行った.

\section{A Study on Image of Old High Streets Using Analysis of Memories on The Street* By Kazuhiro KAMETANI** • Hideo YAMANAKA*** • Masahiro MIYAKE***}

Since it corresponded to the increase in traffic demand in recent years, the bypass, which bypasses the center of commerce in local small-scale towns was fixed. Consequently, Old High Streets became back streets. The center of the town declined. In this paper, to grasp the image, an individual interview was held with along-the-line residents. And it was which expressed the result with rudder structure on the time-axis. A small number of people's focus group meeting was also found by that grasp of a street image is possible by the same method. The street reproduction concept was proposed from this approach. 